\title{
Design Of Continuous Reflux System Bioethanol Distillator With Production Capacity Of 5 Liter/Hour
}

\author{
Rochmad Winarso $^{1}$, Taufiq Hidayat ${ }^{2}$, Rianto Wibowo ${ }^{3}$, Qomaruddin ${ }^{4}$, Masruki Kabib ${ }^{5}$, Uulul \\ Ilmi ${ }^{6}$ \\ \{rochmad.winarso@umk.ac.id ${ }^{1}$, taufiq.hidayat@umk.ac.id², rianto.wibowo@umk.ac.id ${ }^{3}$ \}
}

\author{
Mechanical Engineering Department, Universitas Muria Kudus, Kudus, Central Java, Indonesia ${ }^{123456}$
}

\begin{abstract}
With the decline of national petroleum reserves, the government has launched a plan to increase the use of biofuels, one of which is bioethanol. Therefore, it is necessary to design bioethanol distillator machine. The research methodology starts from identifying needs, literature study, design concepts, then design and calculation. From the calculation result, the distillator produces 5 liter/hour of ethanol, vapor required 50 $\mathrm{kg} /$ hour, heat required $514102 \mathrm{~kJ}$, and fuel which takes $10 \mathrm{~kg} / \mathrm{hour}$. This machine has a tank with a diameter of $400 \mathrm{~mm}$ and height of $500 \mathrm{~mm}$. Reflux construction using 4 inch diameter pipe, length of $2000 \mathrm{~mm}$, and spiral copper pipe length of $3000 \mathrm{~mm}$. Reflux works to lower the temperature from $100^{\circ} \mathrm{C}$ to $78^{\circ} \mathrm{C}$. Condenser use tube with diameter of $200 \mathrm{~mm}$ and length of $600 \mathrm{~mm}$, length of spiral copper pipe $6500 \mathrm{~mm}$. Condenser is useful to lower the temperature of $78^{\circ} \mathrm{C}$ to $24^{\circ} \mathrm{C}$.
\end{abstract}

Keywords: bioethanol, distilator, renewable energy.

\section{Introduction}

Along with the decline of national petroleum reserves and the issue of global warming, the government of the Republic of Indonesia has launched a plan to increase the use of biofuels. Bio-fuels in the current use are bio-diesel, bio-ethanol and bio-oil. The three types of fuel include environmentally friendly renewable energy and raw materials available throughout the country, if cultivated properly.

Increased rate of energy consumption in Indonesia by $8 \%$ per year, while the world rate is only $2 \%$. Energy consumption is increasing rapidly in line with economic growth and population, Indonesia's energy source is highly dependent on fossil fuels, see table 1 [1]. On the other hand, fossil energy reserves data show that oil reserves are around 9 billion barrels and with an average production rate of 500 million barrels per year, the reserves will be exhausted by 2025 .

As our country is endowed with abundant biodiversity resources and available fertile soil, Indonesia should concentrate on bio-ethanol bio-fuel development. Bio-ethanol is an ethanol made from bio-mass containing starch or cellulose components, such as cassava and molasses. In the industrial world, ethanol is commonly used as an ingredient of industrial derivatives of alcohol, mixtures for liquors such as sake or gin, as well as pharmaceutical and cosmetic raw materials [1]. 
Table 1. Availability of Indonesia's fossil energy [1]

\begin{tabular}{lccc}
\hline \multicolumn{1}{c}{ Fossil energy } & Crude oil & Gasses & Coal \\
\hline Resources & 86.9 billion barrels & 384.7 TSCF & 57 billion Tons \\
Reserves (Proven + Possible ) & 9 billion barrels & 182 TSCF & 19.3 billion Tons \\
Production per year & 500 million barrels & 3,0 TSCF & 130 million Tons \\
Availability (without the reserve & 23 & 62 & 146 \\
exploration/production) year & & & \\
\hline
\end{tabular}

The design related to distillator machine has been developed by Winarso, Nugraha and Santoso in 2014 [2], from the results of his research shows the highest level that can be produced from bioethanol distillator machine with reflux system is $92 \%$ with raw material of cassava fermentation.

The research results of Winarso [3] with the following specifications: tank diameter 500 mm, tank length $1200 \mathrm{~mm}$, made of 304 stainless steel with thickness $2 \mathrm{~mm}$, tank capacity 260 liter. From the test results with fermentation molasses for 36 hours produce 3.8 liters of $76 \%$ [3].

With the research of continuous system reflux distillator model with production capacity of 5 liter/hour is expected to help and contribute in the development of renewable fuels that will answer the solution of the problem of petroleum energy shortage in the future.

\section{Methodology}

This research methodology is started from field observation and literature study, identifying needs and generating concept, then do design and calculation. Preparation phase begins with the process of collecting data on bioethanol making materials and manufacturing processes based on the available references. After the data collected proceed with the process of determining the specification of equipment distilator bioethanol. The implementation phase starts with the design of the distilator design, dimension planning and the material of the distiller's tank, the calculation of the required heat, the calculation of fuel requirements, the thickness of the tank distiller's wall, the distiller tank reinforcement design and the working drawing. The next stage is the stage of making the equipment consisting of making the framework, making plendes, making tank distiller, condenser manufacturing, assembly and finishing process. The testing stage is done after the distillers is finished. This stage is necessary to know the performance of the equipment that has been made. Tests conducted on the main material is the fermentation of sugarcane. Testing of fermentation result from sugarcane is done by using variable change that is fermenter type and fermentation process. The method used in the show in Figure 1 

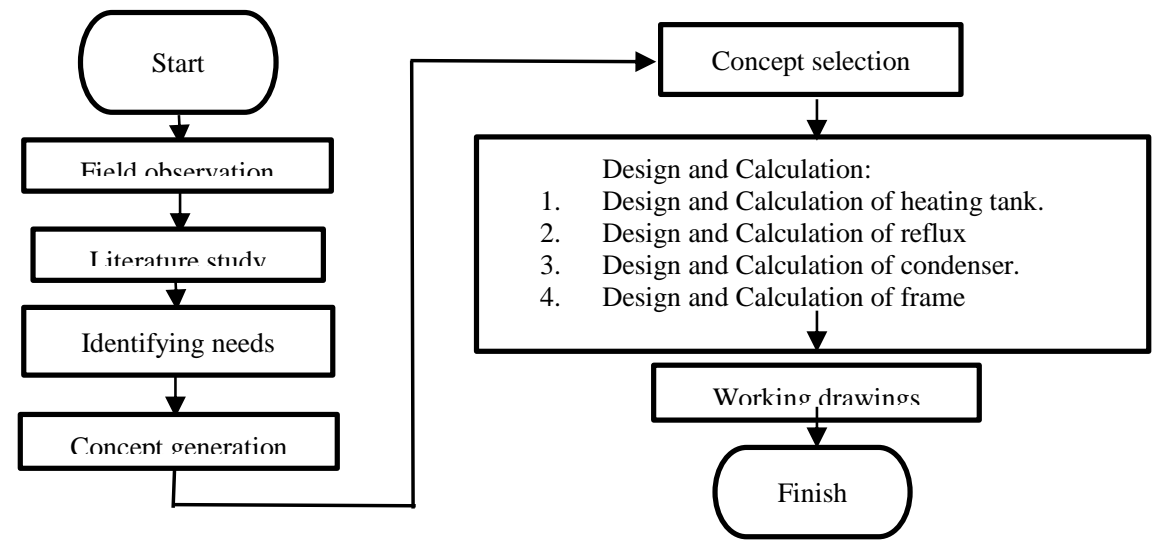

Fig. 1. Flow diagrams.

From several aspects of the selection of concepts referring to the previous research can be concluded that the selection of the most efficient design concept is the concept as follows in figure 2 .

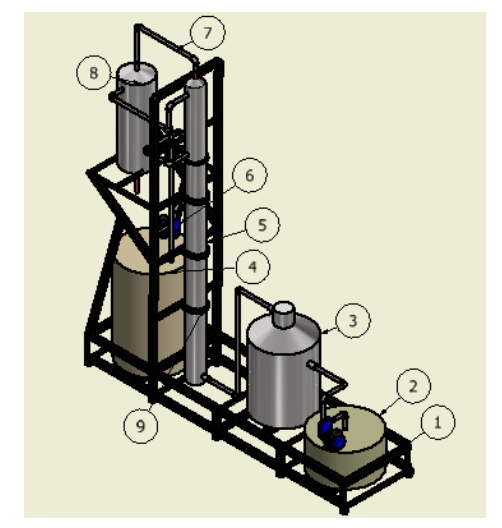

Fig. 2. Distillator.

Notes:

1. Frame

2. Raw material tank

3. Heating and Evaporation Tank

4. Water tank

5. Reflux tower

6. Pumps

7. Pipe connection

8. Condenser

The working principles of the continuous reflux system distillator are as follows:

1. Liquid raw material containing $10 \%$ ethanol and $90 \%$ water put in the tank. 
2. Liquid raw material is pumped and sprayed into the heating tank through the sprayer.

3. Raw materials will evaporate due to heating in the tank. Some raw materials that have not become steam will flow to the bottom of the tank.

4. The raw materials continue to be heated and evaporated, when the raw materials run out then the control system that control the continuous system will work and fill the raw materials back into the tank.

5. The steam in the heating tank will flow to the reflux tower through the zeolite stone for filtration. Steam that has a water content will drop down and will be discharged through the sewer. While the vapor that has ethanol content will flow into the condenser for cooling and ethanol will come out through the condenser outlet.

\section{Result and Discussion}

\subsection{Heating Tank}

The heating tank serves as a site for producing high-pressure steam to be used for washing the alcohol in the distillation column. Figure 3 below is a picture of a heating tank:

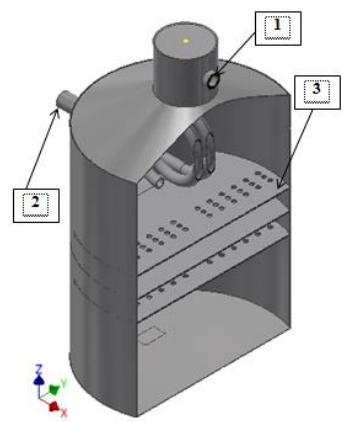

Fig. 3. Heating Tank.

Calculations in the design of heating tanks, among others, to find the needs of steam, heat needs, fuel needs. To find the needs of steam is the production capacity to be achieved divided by the content of beer raw materials to be used. To find fuel consumptions is the total heat requirement divided by the heat value of the fuel used. The calculation in the design of the heater tank is based on several formulas as in formula 1-4 with the results in table 2 .

Table 2. Calculation Result.

\begin{tabular}{lc}
\hline \multicolumn{1}{c}{ Calculation } & Result \\
\hline Steam needs & $50 \mathrm{~kg} / \mathrm{hour}$ \\
Calor needs & $514102 \mathrm{~kJ} / \mathrm{hour}$ \\
Fuel consumptions & $10 \mathrm{~kg} / \mathrm{hour}$ \\
\hline
\end{tabular}




\subsection{Reflux and Condenser}

This distillator uses a reflux model, which is a multilevel distillation. Repeated distillation occurs in fractional columns, fractional columns consisting of several barriers and there is a filter where in each part there is condensation and filtration, see figure 4 . The steam in the higher barriers contains more ethanol. Condenser is the most important part in each distillator machine, condenser serves to remove the heat and change the gas form to liquid.

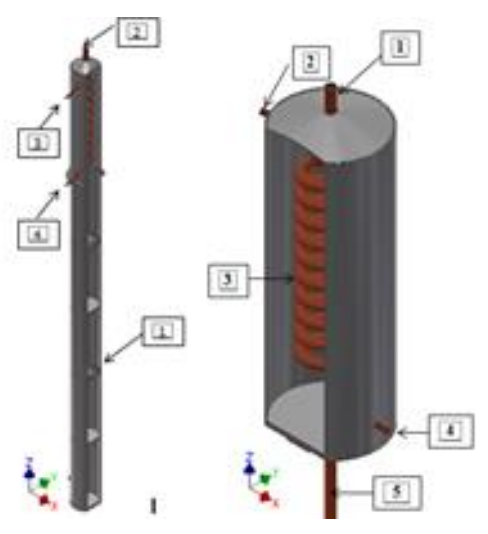

Fig. 4. Reflux and Condenser.

The calculation in the design of reflux and condenser is to find the value of LMTD, correction factor, reynolds number, nuzelt number, heat transfer convection coefficient, total heat transfer coefficient, heat, surface area, pipe length, pitch number, pitch distance, based on some formulas as following.

Calculations in reflux and condenser designs are based on several formulas with the results in tables 3 and 4 as follows:

Table 3. Reflux.

\begin{tabular}{lc}
\hline \multicolumn{1}{c}{ Calculation } & Result \\
\hline LMTD & $60.2^{0} \mathrm{C}$ \\
Total Heat Coeff (Uo) & $0.00018 \mathrm{~W} /{ }^{\circ} \mathrm{C}$ \\
Heat (Q) & $0.007253 \mathrm{~kW}$ \\
Pipe surface area (A) & $0.152 \mathrm{~m}^{2}$ \\
Pipe length (L) & $3000 \mathrm{~mm}$ \\
Pitch (n) & 24 \\
Pitch distance $(l)$ & $20 \mathrm{~mm}$ \\
\hline
\end{tabular}


Table 4. Condenser.

\begin{tabular}{lc}
\hline \multicolumn{1}{c}{ Calculation } & Result \\
\hline LMTD & $40.8^{\circ} \mathrm{C}$ \\
Total heat coeff (Uo) & $0.00022 \mathrm{~W} /{ }^{\circ} \mathrm{C}$ \\
Heat (Q) & $0.0032562 \mathrm{~kW}$ \\
Pipe surface area (A) & $0.426 \mathrm{~m} 2$ \\
Pipe length (L) & $6500 \mathrm{~mm}$ \\
Pitch (n) & 12 \\
Pitch distance $(l)$ & $50 \mathrm{~mm}$ \\
\hline
\end{tabular}

Based on the calculation process above, a bioethanol distillator design has been produced, the continuous system reflux model has a production capacity of 5 liters/hour, with complete specifications as follows:

a. Frame

1. Main frame : Steel ST 37 profile L dimension is 30 x 30 x $3 \mathrm{~mm}$

2. Supporting frame : Steel plate with $2 \mathrm{~mm}$ thick.

b. Heating tank

1. Materials : stainless steel plate 304 with $2 \mathrm{~mm}$ thick.

2. Diameter : $400 \mathrm{~mm}$

3. Height $: 500 \mathrm{~mm}$

c. Reflux

1. Materials : stainless steel plate 304 with $1 \mathrm{~mm}$ thick.

2. Diameter : 4 inch

3. Length : $2000 \mathrm{~mm}$

d. Condenser

1. Materials : stainless steel plate 304 with $2 \mathrm{~mm}$ thick

2. Diameter $: 200 \mathrm{~mm}$

3. Height $\quad: 600 \mathrm{~mm}$

e. Coil pipe inside reflux

1. Materials : copper $1 \mathrm{~mm}$ thick.

2. Diameter : $3 / 8 \mathrm{inch}$

3. Length $: 3000 \mathrm{~mm}$.

f. Coil pipe inside Condenser

1. Materials : copper $1 \mathrm{~mm}$ thick.

2. Diameter : $1 / 2$ inch

3. Length $: 6500 \mathrm{~mm}$.

\section{Conclusion}

From the calculations that have been done, can be taken some conclusions as follows:

1. Tank using stainless steel plate 304 with diameter $400 \mathrm{~mm}$, length $500 \mathrm{~mm}$, and thickness $2 \mathrm{~mm}$.

2. To produce a product capacity of 5 liters/hour, a tank of 25 liters is needed, using corn cobs with $10 \%$ alcohol content and $90 \%$ water, 37.8 liters of evaporation volume, $50 \mathrm{~kg} /$ hour steam requirement, $514102 \mathrm{~kJ} /$ hour, and fuel consumption 10 $\mathrm{kg} / \mathrm{hour}$. 
3. Reflux using stainless steel pipe 304 diameter 4 inch, length $2000 \mathrm{~mm}$ and thickness $2 \mathrm{~mm}$.

4. The heat exchanger inside the reflux functions to reduce the temperature from $100^{\circ} \mathrm{C}$ to $78^{\circ} \mathrm{C}$ using a $3 / 8$ inch copper pipe with a length of $3000 \mathrm{~mm}$, with details of the LMTD value of $60.2^{\circ} \mathrm{C}$, the total heat coefficient is $0.00018 \mathrm{~W} /{ }^{\circ} \mathrm{C}$, heating value $0.007253 \mathrm{~kW}$, pipe surface area is $0.152 \mathrm{~m} 2$, number of pitch 24 , pitch distance 20 $\mathrm{mm}$.

5. Condenser using stainless steel plate 304 with diameter $200 \mathrm{~mm}$, length $600 \mathrm{~mm}$ and thickness $2 \mathrm{~mm}$.

6. The heat exchanger in the condenser functions to reduce the temperature from $78^{\circ} \mathrm{C}$ to $24^{\circ} \mathrm{C}$ using a $1 / 2$ inch diameter copper pipe with a length of $6500 \mathrm{~mm}$, with details of the LMTD of $40.8^{\circ} \mathrm{C}$, the total heat coefficient displacement $0.00022 \mathrm{~W} /{ }^{\circ} \mathrm{C}$, heating value $0.0032562 \mathrm{~kW}$, the pipe surface area is $0.426 \mathrm{~m} 2$, the number of pitch is 12 , the distance between the pitch is $50 \mathrm{~mm}$.

\section{References}

[1] E. Hambali, S. Mujdalifah, A. H. Tambunan, A. W. Pattiwiri, and R. Hendroko, Teknologi Bioenergi, 2nd ed. AgroMedia Pustaka, 2007.

[2] R. Winarso, B. S. Nugraha, and T. Santoso, "Pengembangan Alat Destilator Bioetanol Model Refluk Bertingkat Dengan Bahan Baku Singkong," J. SIMETRIS, vol. 5, no. 2, pp. 97-104, 2014.

[3] R. Winarso, B. S. Nugraha, A. Muttaqin, and N. Rofiudin, "Pengembangan Alat Destilator Bioetanol Sebagai Bahan Bakar Alternatif," Pros. SNST Fak. Tek. Univ. Wahid Hasyim Semarang, vol. 1, no. 1, pp. 7-12, 2016. 